\title{
Knowledge Growth and the Re-Invention of the African Mind for a Philosophy of Progress in Africa: A Critique of the Westernization/Eurocentric Discourse
}

\author{
Uwalaka Jude N. (PhD) \\ Department of Philosophy of Science and Technology, Federal University of Technology, Owerri, Nigeria
}

\begin{abstract}
There is a consensus that given the myriads of crisis besetting Africa, that she must find a new direction, a re-invention of the African mind, and an appropriate philosophy of progress.

The question then is, what will such a philosophy of progress and re-invention that is tailored to the African condition be like? Among the visions being espoused and proposed by some is the Westernization paradigm of development, what some call the Eurocentric discourse, which claims that Africa has no alternative than to rediscover the Westernization agenda started by colonialism, a better and more effective immersion into Western civilization understood as the universal and natural path to human, cultural, material and social progress. Our essay here tries to review this Eurocentric discourse, her claims and presumptions, and those of her critics. We tend to articulate a position which lies in Africans having a critical engagement with what western civilization has offered and continues to offer, with a view to appropriating only those ideas, visions and methods which, in combination with relevant African heritage, will unleash her indigenous potentialities in order to ensure a progressive path, respectable well-being and dignity for her people in the future.
\end{abstract}

Keywords: African heritage, African mind, colonialism, knowledge, progress, westernization.

\section{Introduction}

There is no doubt that Africa is suffering the crisis of modernity, not because it is very modern but because it appears to be caught in a no man's land. Though not modern enough because of her deficiency in the many indices of development which people have come to associate with modernity yet all the paraphernalia of the government and her external impressions in the urban areas appear to have the imprint or modernity. Modernity in this work is in reference to what people call liberal western modernity. It is equally not considered indigenous enough because her cultural and indigenous practices appear to be stagnated, and most of it being lost due to neglect and the quest for western values. The resultant effect is an Africa in plain crisis of being and having, in real need of progress, in search of her positive destiny in the world; an African in need of mental reinvention, as a lot of negative indices on Africa today can demonstrate.

The crises of being and living in our African world today can also be seen in the lack of originality, copycatism, dearth of bold and grand ideas, gross absence of creative and inventive production, social and economic stagnation, low quality of life, lack of self-confidence and loss of direction, dependency syndrome, low productivity at all levels, paralyzing poverty, inability of effective harnessing of the evident abundant human and material resources, a grave yard of talents, consumerist mentality, a certain inferiority complex and mediocrity as a way of life; decreasing culture of excellence, fascination with the foreign and creative wonders of other peoples; stoic surrender to the statusquo, improper sense of resignation, poor organization of the sociopolitical space, incoherent and unsuitable ideological policies or lack of it, collapsing cultural and educational institutions, uncritical intellectual culture, endemic corruption, moral degeneration, endemic violence and an apparent comfort in playing the second fiddle in the world.

Many have reduced these to the problem of the mind. The central problem then is, what are the fundamental causes of such mental deformation and disorientation, which have put Africa on the path of retrogression and obsolescence. Before we enter into this, it is worthy of note that the African society or societies are not static. It has passed through many epochs and processes and have been subjected to many influences, conscious or unconscious. In fact the most part of what may be called the modern period today, could be said to be the Africa created, directed and imposed by non-Africans. Thus talking of the African mind is to talk of the various tributaries that has come to shape the African mind, which are both internal and external. For the sake of this write up, we can identify three grand currents in the building of the modern African mind.

1. Colonialism/neo-colonialism and its so called modernization effects and westernization project.

2. The African traditional culture, which has also resisted attempts at total obliteration.

3. The contemporary globalization trends and the tendency towards cultural hybridism and anarchy. 


\section{The Westernization And Eurocentric Discourse}

In this attempt to identify the sources or causes of the deformation and disorientation of the African mind, a lot of blame game has been going on between different groups which may be ideological, political, cultural, philosophical, religious, and economic. Each group has tended to present its own picture and reasons for what has happened and continue to happen to the African mind and world, leaving Africa in a terrible crisis of social, cultural and human well-being. Among the many diagnosis and solutions that have been proposed for the re-invention of Africa, and for African progress is the full realization of western modernization of Africa which according to the proponents was badly implemented or even abandoned due to diversions or distractions raised by ideological and philosophical opponents, the consequences they claim are the complications and crisis we have in Africa today.

The object of our analysis in this work is this Westernization and Eurocentric discourse on the Africa situation and her diagnosis and presumption for the reinvention of the African mind and society, and her philosophy of progress for Africa.

The Western-modernist oriented thinkers are those who accepted the necessity and indispensability of the European westernization incursions and project in Africa. They see colonialism and the neo-colonial activities in Africa as a necessary evil which came to launch an attack on a greater evil which they regarded as the obstructionist, old fashioned, undeveloped, disorienting and deforming effects of the African culture and tradition on the African mind. Thus for them, the African traditional mind is uncivilized, uncultured, and unenlightened and hence the need for a Western civilization project and programme in Africa. Their arguments, prognosis and prescriptions are clear, namely that for Africa to develop and progress her mind must be transformed to be like the European mind.

In essence, western liberal civilization and culture is seen by the protagonists as the highest civilizational attainment by man. According to Arnold Toynbee, Walterstein, F. Hayek, and others this civilization is regarded as the apex of man's cultural achievement.

Africans were seen as the other, who must be made or forced or absorbed into a universal civilization seen as Western liberal civilization, the defense of which we called here a Westernization or Eurocentric discourse.[1] This position embodied some of the eurocentric and racist anthropological theories prevalent in the Western world as can be seen among some early modern European philosophers, like Hume, Kant, Hegel, Voltaire etc.

We recall Hegel's infamous words in 1830, “. . . the negro . . . exhibits the natural man in his completely wild and untamed state . . for (Africa) is no historical part of the world; it has no movement or development".[2]

Hume earlier in 1768 had said "I am apt to suspect that the negroes . . . to be naturally inferior to the White. There never was a civilized nation of any other complexion than white, nor even any individual eminent, either in action or speculation. No indigenous manufacturers among them, or arts or sciences. [3]

Many other infamous statements from well known Western philosophers are well documented and known. These ideological and philosophical depreciation of the Africa have been summarized by W.E. Abraham thus:

Attempts have for sometime been made to represent Africa as a sort of colossal tabula rasa, blank sheet, where culture is concerned... there is the view that while other continents have for a long time shaped history, Africa has been enmeshed in a sort of a historical morass, it has only recently broken upon history. Its history, as it were happened to it. There is also the view that the genuine Africa, the Africa of the man in the bush, is so near to pure nature that in Africa one beholds humanity virtually in its infancy.[4]

The aim of highlighting some of these negative stereotypes here is not to continue to ventilate these slurs against Africa but rather to show some of the reasons whether good intentioned or not, why the westernization/modernization route was regarded as the only model for African progress and why it has also been bitterly resisted by some others. For these western-modernist thinkers, to develop Africa, is to offer to Africa the so called "privilege" and gift of western civilization which is seen as universal civilization.

\subsection{The making and Elements of the Westernization/modernization Process.}

Westernization is a western styled modernization process, or set of processes, a distinctive tradition with economic features which came to be identified with a unique civilization that belongs to the EuroAmerican world. This civilization assumes to have uncovered and embodied the basic and essential structures of human life, thought and discourse. Modernity in this perception meant a preoccupation with history as linear not cyclic. History is a narrative infused with the drama of the possibility of progress. This theory claims to explain the course of history in terms of vast impersonal forces and stipulate that history is a series of inevitabilities independent of individuals' political wills and choices. 
It leveled and homogenized reality, and thus claimed to possess the model of universality and objectivity in most areas of human knowledge and value system. It is seen as a universal paradigm for human cultures, knowledge, progress, the creation of wealth, human and social understanding in general. Western modernity helped by the rise of modern science blossomed in the $18^{\text {th }}$ century with the industrial revolution, forced by its ideology of unlimited progress through capitalist mode of production. It gathered momentum and geographical extent by conquest, by imitation and colonization.[5] Marlene Van Niekerk trying to explain the state of mind that motivated the modernizers said "violent subjection of the "Other" could be construed as an act of civilized man with an intent to civilize, to bring light into the darkness of those minds that had been excluded from the scientific fruits of the European Enlightenment".[6]

This Western modernity which became synonymous with the philosophy of westernization as a philosophy of progress will uphold transhistorical reason triumphing in the world, triumph of instrumental reason, penetration of the scientific vision of the world, almost canonizing the philosophies of positivism and empiricism, with its liberal, social, cultural, and political component. The modern is associated with complexity, heterogeneity, differentiation, secularization and technological advancement whereas the traditional is linked with underdevelopment, the primitive, simple, homogenous, undifferentiated and supernatural influences. Positivistic rationality, and scientific truth became acceptable norm and measure. To develop Africa meant then, to westernize or Europeanize Africans, which is a process by which western/European society and values must be replanted into Africa and the African man must empty his africanness to be become what Franz Fanon called "black skin, white mask".

Thus the westernization process presented European ways as the ideal culture; the European mind as the ideal mind; his rationality as the ideal rationality, while Africans and their cultures are the opposites both in their epistemic and value systems. It is the contrast between rationality and irrationality, open and closed mind or society, scientific and religious; conceptual and perceptual, logical and pre-logical, civilized and savage. Whereas Europe is supposed to incarnate the first of each category mentioned; the African is in the second. Modernization and westernization then meant enlisting Africa into the grand project of western enlightenment which was a revolution against authority, tradition, faith, transcendence and the supernatural. It would involve a democratic, political system centering on individual rights and choices. Economically it meant the accumulation of wealth through the judicious pursuit of self-interest, and socially, the emergence of a deep separation between the private and public spheres of life. Knowledge-wise, scientific rationality becomes the ideal and motor which must drive society.

The sum total of the above was identified with progress and development which claimed to hold a glorious destiny for the world if all embrace it. The westernization project was equated with the inevitability of human progress as was posited by the $19^{\text {th }}$ century positivists like August Comte. Thus, the Eurocentrists and their African converts argue that for Africa to survive and develop, it must embrace the revolutions of European modernity: the intellectual revolution of materialism, the political revolution of equality and above all, the scientific and technological revolution.

The consequence, of these for them is that for Africa to enjoy a real mental renaissance or re-invention and social advancement, they must embrace the promises of westernization or liberal modernity and its dogma of development which summarizes the enlightenment vision of Jefferson, Adam Smith, Kant and Condorcet, namely:

i. To foster political systems that promote human well-being based on the consent of the governed.

ii. To foster economic systems that spread the benefits of science, technology and the division of labour all over the world.

iii. To promote science and technology grounded in human rationality to fuel the continued prospects to improving the human condition.[7]

In a warning to cultures and societies which would fail to follow this western epistemic, socioeconomic and developmental paradigm. C.E. Ayres said ". . . the technological revolution is itself irresistible, the arbitrary authority and irrational values of the pre-scientific, pre-industrial cultures are doomed. Three alternatives confront the partisans of traditional values and beliefs. Resistance if sufficiently effective though it cannot save the tribal values can bring on total revolution or ineffective resistance may lead to sequestration like that of the American Indians. The only remaining alternative is that of intelligent voluntary acceptance of the industrial way of life and the values that go with it"[8]

The western education system was introduced to shape the African mind, in the likeness of the European mind, to implant the so called official ideas. The mind of the African people are taken to be a "tabula raza" a clean state, a completely virgin land, which must be shaped to conform to universal ideas, that is the European ideas, aimed at producing exact clones of the European mind. Walter Rodney explains that colonial education sought to instill a sense of deference towards all that was European and capitalist to ensure that the colonized maintained solid psychological bond with the metropole to ensure that they remain European in language, thought and spirit.[9] Thus a lot of African Elites who lay claim to political, scientific and cultural 
authority and superiority thanks to western education became demonstration agents of the westernization ideologists. They equally hold that Africans should conform to standards imported from the west as the representative of universal standards. It is a position which accepts the dissolution of the African personality into systems of values and structures of the western cultures and mentality.

African mind had to be projected in fact, without any thorough analysis and dialogue, into the Western Aristotlelian paradigm of binary oppositions where she is categorized into the first negative molds; uncivilized versus civilized. Pre-logical versus logical, mythical (pre-scientific) versus scientific; pre-critical versus critical, emotive versus rational, pre-reflective versus reflective. Horton presented such prejudices and for him, false dichotomies between African traditional thought and western thought, thus; intellectual versus emotional, rational versus mystical, reality-oriented versus fantasy-oriented, casually oriented versus supernaturally oriented, empirical versus non-empirical, abstract versus concrete, analytical versus non-analytical.[10]

Given this categorization of the African mind, progress, well-being, understanding reality meant the exorcising of the African mental idols, and reconstruction or changing the African mental categories and perspectives in the mold and likeness of the European mind which people call Euro-centricism. Westernization thus tried to forge a normative philosophy of human culture as a whole.

The problems of Africa today are therefore laid on the door of the unfinished project of westernization. They claim that African problems must be blamed on the relics of traditional culture which has continued to disorientate the African mind making it impossible to adopt or face the realities of our world today. Some of these agents of westernization, will see iconoclasm as the way to the future that is, extirpation of African tradition is the step to freedom.[11]

It would be a radicalist solution which would tend to obliterate anything African in the African mind, which we can call an iconoclastic attitude to the African mental reality. This means a declaration of a discontinuity between the African past, her traditional epistemic, moral, aesthetic, cosmogonic and cosmological categories, and analysis of reality, and what she needs for the present and future, if there must be a mental reformation or re-invention or mental renaissance. Westernization or western-oriented modernization then was supposed to bring about this new Africa mind and rationality. The effect is what Chinua Achebe will call "things fall apart and no longer at ease".[12] Modernization of the African mind meant then as Mudimbe (1988) would say, the process of organizing and re-organizing both the structures and the mind. He highlighted how the so called western scientific discourses on Africa were nothing but the product of western cultural priorities and prejudices and portraying their own Western orientation. Her discourse was invented to mark off the African and Africa as the other of the West ordering the world with the West at the center.[13]

When it is realized that some of the great western intellectuals like Hegel and Trevor Roper had already said that Africans had no history, it would mean that "there was no African past, nothing of value, neither their customs, nor their cultures. The implication then is that Africa was expected to take on the customs, the logic and the language of the colonizer. He had no future of his own to look forward to, and hence it was incumbent upon the generous and caring white man to carve out a future for him, thus, perpetuating the myth, of the African as the white man's burden".[14]

The school system became a vehicle for this systematic destruction and uprooting and re-plantation into the western devised categories and world view, under the philosophy of the quest for universality and objectivity. Many African intellectuals came to buy this ideology of western culture and imperatives as a true representative of the universal standards. Africans were then held to be incapable of ruling themselves because of primitive irresponsibility. Therefore they need enlightened masters to show them the ways of superior civilization and deliver them from ignorance.

\subsection{The African Intellectual Westernizers and Demonstrators}

Most of the African intellectual converts have tested the western life style and called for the adoption of western culture and mental categories and even language as the authentic African way. These Westernoriented Elites who still constitute an overwhelming majority of the African Elites today, and those who direct affairs in the continent came to represent a mentality that would not like to identify with most of the African ways which for them symbolized the state of savagery. Hence their recommendations for a head long plunge, into western civilization. Mwite Mugambi said it all:

Colonization and westernization have brought a permanent and irreversible change in Africa... As long as we continue talking of Africanity and going back to the root, yet we remain quiet on the reality of modern society, we will sound foolish, outdated and out of touch with reality... what African writers and scholars should do is deal with issues that are afflicting our society. . . than waste time on the issue of Africanness . . then the effects of westernization are here to stay and the faster we adapt to living with them, the better for us and the generations to come.[15] 
This fascination and longing for whatever is western still remains the dominating attitude and mentality of the African Elite and the aspiration of the younger folk. This manifests their conviction that African cultures and epistemic categories are far inferior and cannot meet the standards of a high culture. The white man himself is almost regarded as a spirit, the model and quintessence of a true human being whose values, mannerism and even his mistakes must be assumed without much ado.

The westernized African is aptly portrayed by the African writer - Okot. P. Bitek- in his song of Lawino and song of O'col. Lawino lashed at O'col for abandoning his ancestors and cultures. O'col was a prototype of westernized African iconoclast, very pessimistic of Africa. For him there is nothing in the Africa past to regret. All we have is backwardness in technology; anachronistic clinging to out-moded forms of government and medicine. He will not go back to repent to the ancestor.

He would rather destroy the homestead, uproot the pumpkins, and traditional cultures that have held Africa down including: Negritudinists and Pan-Africanists.[16] The Euro-centric offspring in Africa today comes under the name of post Africanists, among whom are people like Dennis Ekpo, Chielozena Eze, Abiola Irele, Towa, Lansana Keita, Hountondji. These are the radical supporters of Western rationality and cultures in the re-invention of Africa. The crux of the arguments of these radicals is based on African self-interest and survival, which they think is most enhanced in the tactics of espousing the same techniques and instruments of western denomination as a tool for African emancipation and competitivity in the world.

Some statements by some authors and philosophers seem to buttress the above point. One such statements is that of Chielozena Eze when he said:

...Africans instead of directing their dissatisfaction to their oppressive religion and morally depraved rulers as well as against residues of primeval cultural forms, that prevent the flourishing of life, turn their anger at concepts traditionally associated with the west, the sworn enemy, such as colonialism, imperialism, and globalization etc.[17]

In a recent rebuttal of those who would blame the West for African woes and failures he declared that the hatred for the west creates in the African a combative state, which hinders the mind from engaging in a somewhat, dispassionate analysis of the world. The individual is forced to tread on her convictions acquired through her own engagement with the world. A part of her, recognizes that some aspects of her native culture no longer supply adequate answers to most existential questions of her times yet she is forced to cling to those aspects for the simple reason that they are her own peoples heritage.[18]

Corroborating the above, Themba Sono declared: "Our intellectual environment is deformed". He goes on to say that this deformity is based on "traditional forms of superstition, intolerance, sloth, indolence..."[19]

Ekpo in his post africanist model seem to espouse the Hegelian prejudices about Africa and see African history in dialectical terms when he said:

Post africanism points towards a more creatively productive future time when post-colonial subjects were released from their erstwhile compulsive anti-west resentments and fully reconciled with their historical fate, as offspring of Europe's defeat, will discover anti-anti imperialist spirit, to love and celebrate the fact that we were once colonized and through being colonized were happily fast-forwarded into the theatre of world history.

He will go on to say "there can be no African path to development except the wrong path, no specific African way or Africanity different from the ways of preliterate cultures stuck in the mythico-magic consciousness and waiting for rational-scientific technological Enlightenment".[20] Abiola Irele on his own will say "I do not see that any necessary ground for repudiating western rationality has been provided. It is not enough to say that Africans need a kind of conceptual autonomy. What we really want to know is whether the western system provides useful ideas ..."[21]

Emphasizing that there was no other route to free herself from past obstructive traditional attitudes in order to gain access to the secret of their defeat Towa would say "in order to affirm and assume oneself, the self must deny itself, it must deny its essence and therefore its past, it must expressly aim at becoming like the other similar to him and hence uncoloniziable by him".[22] In similar presentation, Jean-Maria Makang warned, "if the African people lack what allowed westernizers to conquer the world in modern times, mostly technical efficiency, they will be forced to remain under the control of the west. However, the reason for this superiority of white man is his control over natural forces"'[23]

Many other African philosophers and epistemologists have defended a universalist standard of rationality and the obeying of universal canons everywhere to the detriment of particularism, though, they may not be as radical as the post Africanists and other African radical Westernizers. They are nevertheless accused of supporting the Western-modernist paradigm of development in Africa. These would include Kwasi Wiredu, Gyekye, Gbedegesin, Bodurin, Masolo etc.

Their argument is that human beings everywhere are the same. Reason has no color, and no race. It obeys the same laws. Hence they postulate a neutral, critical reflective reason which is universal and crosscultural. This culture of rationality for them has been discovered within the European Enlightenment revolution 
in which the spirit of modernity is born. This is the revolution that elevated reason over faith, emotion, authority, and tradition.

Thus, like the Europeans of the enlightenment period, Africans are challenged to dare to think. By this they mean, the imbibing of the so called disinterested curiosity, the rigorous logic, the unpessimistic and unresigned skepticism, the geometrical spirit and the committed and audacious researching spirit which are the secret that have brought the western man to the wonders of the scientific and technological breakthroughs: the wonders of the industrial revolution, of the atomic revolution, the genetic revolution, information revolution, the computer and digital revolution etc. For them the road to progress has been paved, its epistemic and ethical contours have been discovered. Some according to Masolo place emphasis on the scientific and the modern as advanced developmental stages in the dialectical transformation of knowledge and technological means, and Africans need to transform their world towards this level.[24] Thinking in the same light, Gyekye abhors the fact that the ancestors continue to be of paramount importance in modern and traditional African life. For Africa to progress scientifically and technologically, science should be rescued from the morass of traditional African religious and mystical beliefs. He would argue that only those cultural values and practices that could be accommodated into the African modernity after underlying refinement, to bring it in harmony with the spirit of modern culture should be adopted.[25]

The argument then is that Africans cannot undo the past or erase the cultural and epistemic consequences of the European colonialism. They are said to be irreversible and that Africans have crossed the border of no return. Africans are instructed to recognize the intrinsic instrumental value of some of the more technical varieties of information and methods of reflection such as the scientific method that colonial experience has put at their disposal which are conceived as neutral and instrumentally useful elements.

Some of African philosophers may even suggest a type of "cartesian approach" or a total bracketing of the African culture or world-view. Africans must become a clean state to allow the neutral reason to operate. Summarizing this view and in support of Towa, Irele said, "if the spirit of the traditional past is operative in the present and it is understood that the immersion of traditional men in that spirit is responsible for our conquest and domination by Europe, then we should seek out the secret of the power which overwhelms us and ascertain the direction from which it came". This power was located in the European practice of rationality, the key to the scientific and technological progress. Africans are thus cautioned and called upon to exorcise their obsession with originality and difference based on any so-called indigenous genius.[26]

For these then, progress lies in the transition from particularism to a universal scientific culture. In all, the defenders of the westernization process and its so-called enlightenment agenda, feel that the apparent failure of the western modernity project in Africa is because the westernization process was not allowed full time to mature and blossom, by the oppositions of the nationalists and their desire for independence. Hence, it is argued that what happened in Africa was only a superficial encounter with the west as the African mental and psychological world remained unrepentantly African.

Some have even argued that the most depressing moment in the African political history was our attainment of political independence, the moment we cried for it. Unfortunately, according to this thesis, we were not ready and may never be, as can be shown according to them from the glaring current predicament. This argument has prompted some to call for a re-colonization of Africa. Of course, we know that the voice of the recolonization thesis is heard in many western conservative groups even till today. The argument is that the failures in Africa today can be likened to the misadventure of a bad apprentice who quit learning before he was fully formed, certified himself ready, and discharged himself from tutelage. This apprentice for them will end up a bad workman quarrelling with his tools. Thus for these neo-colonizers, the problem in Africa is the unfinished westernization process or a westernization aborted before viability and reinvention.

Their solution then to the African quest for progress and mental renaissance, is not less but more westernization. This of course is in line with the main broad solution of many of the proponents of westernization, namely the obliteration of the African culture which for them is heavily tainted. They point to the prevailing and suffocating influence of juju and the belief in juju and other such practices which are still deeply rooted in many African societies, regardless of education, religion and social class of the people concerned. And in the words of Kofi Akosah-Sarpong:

Like any other culture, this aspect of the African culture is irrational and blinds one from realistic assessment of problems, ... . such counter-productive thoughts by African elites show how the irrational African cultural values appear to outweigh the rational parts and how such patterns persist in Africans' development process. While the scientific side of the African mind demands objective evidence as to why juju should influence them, their brains mythopoetic irrational juju thinking side entices them to irrational marvels, to evil spirit, juju or demons. [27]

For these African westernizing modernizers, the extirpation of tradition is the first step towards freedom. Through such changes they argue, Africans are fortifying their universalist abilities to the detriment of particularism and getting ready to embark in a similar process of empowerment which makes them 
unexploitable and uncolonizable.[28] Thus for a true progressive march in Africa, it is then proposed that the African elite should rethink the relationship between their culture and progress especially how to refine the inhibitions within their culture to facilitate progress as the Europeans did during their enlightenment struggles, in their development process. The arguments here appear to highlight the fact that culture issues are not only modernization issues but also progress issues. Hence culture is a serious progress issue.

\section{Critique Of Westernization And Eurocentric Discourse}

This westernization paradigm and its iconoclastic approach as a road to the re-invention of the African mind, growth of knowledge and progress of Africa, have been and are being battered by critics who see it as a case of a killer dancing at the funeral of its victim. Some affirmed that with the racist distortion of the African humanity, by the western colonial Anthropologists and philosophers, Africa was inflicted with a stigma and has been the "Other" of humanity who required liberation and caused to have a marginal place among people's and nations. This marginality and racist attack are clear from the discriminations and neglect, which Africans suffer among peoples from other races. Today no people have had their humanity so degraded and their dignity wounded and so "unwanted" as the black man in Africa and in the Diaspora.

Critics query how a civilization and its philosophy which have inflicted such damage to Africa could be the instrument for her regeneration and re-invention.

Furthermore, many are not ready to concede that Africans have gained or achieved the often proclaimed material prosperity said to have been triggered by the westernization modernity as most of Africa continue to wallow in grave socio-economic and political crisis and paralyzing dependency, created by her appendage to the western world. In the westernized modernity, societies are divided between winners and losers, coexistence of superfluity and penury, misery and extreme opulence which are taken to be the natural ways of things. Though there was poverty in traditional African societies, but the poor in western liberal modernity is of another nature and species. This is a more degrading type, for unlike in the traditional society, where the poor has some dignity surrounded by caring relations and benefactors, the poor and even the rich of the western modernity lack the contentment of being, dignity in being, stability and joy in living, and the common celebration of a common humanity in the presence of the other, due to the suffocating, calculating and materialistic values, and individualism which have defined liberal Western modernity.

The spirit of western liberal modernity often does not promote or reflect the higher values of the human spirit, like the sense of life with its promotion of the culture of death. The search for meaning, the problem of the good and the ultimate questions of existence are neglected as man is subjected under the bondage of the consumable and pleasurable. Hence one can talk of the impoverishment of the nobility and dignity of our humanity, by the materialism at the root of liberal Western modernity. It is said that behind the glamour and the technological and economic wonders of the western modernity, lies a hidden violence against the moral and spiritual fiber of our human society. Technology is constituted into a god, which man must worship and its spirit of functionality and pragmatism over that of being and the good, an attitude that could be called technolatry. Hence we are launched into a technology driven-world instead of a human driven world; more and more, a technology for economic efficiency and profit making, and less and less a technology for human well-being.

From the womb of Westernizing modernity were born many dangerous ideologies and tools of destruction that have wounded humanity, especially African humanity, like the theories of social darwmism, which brought the survival of the fittest mechanism into human society; Neo-Malthusianism which endorses neglect of the vulnerable by allowing the natural process to blindly eliminate whoever must be eliminated; Nazism which produced the holocaust; and Apartheid, which was a special application of racism in South Africa. The critics especially the Afro-centricists lay the blame for the disorientation or deforming of the African mind squarely on the westernization agenda in Africa, brought about through colonialism and her new forms of neo-colonialism and imperialism.

They argue that this attempted westernization and Europeanization of Africa tried and will continue to squander the African original and indigenous civilization and obliterate the unique historical riches and genius of the African people. They blame the today's abysmal and prostrate state of Africa to an externally induced paradigm of development and conceptualization which Africans have followed since the eruption of the Whiteman in the African world. This made African destiny in the world to be tied to that of the European, where Africans have no weight or relevance and which condemned Africans to imitation, 'satelitism', and dependence through which Africans lost their originality and in which the seed of inferiority complex was sown and continued to flourish. The further consequence which is equally paradoxical is that the more Africans tried to be more European, the more they have been alienated from themselves and also the less European they have become, only to assume a condition that is at best confused, producing a society that is chaotic and rudderless and a quality of life which in general has been less progressive or more depreciative. Westernization for the critics shortchanged Africans proper destiny in the world and substituted for it an imposed destiny, and lost its self-directed destiny and her proper freedom. 
What has emerged is a culture of slavish imitation of the western world and because it is an imitation, it lacks originality and because it lacks originality, it will always at best be a second best and a second rate. This is second best and an imitation which robbed Africa of its dignity and identity and turned her into a slave of an alien world with an alien way of thinking, naïve and consumptionoriented. This alienation constitutes a basic disorientation which Franz Fanon as we said before will call 'Black skin white mask. A situation which makes Africans neither good photocopies nor authentic originals: a state of double corruption and double jeopardy and hence double disorientation. Thus westernization through the agencies of colonialism and neo-colonialism did damage to the African psyche especially in herself confidence and self-appreciation. Africans were turned into copycats, echoing the masters voice in all spheres of life. Some call it mental alienation, or enslavement of consciousness, the consequence is a beggarly mentality of the elite and almost the worship and adulation of everything European among Africans no matter the rank and the level of education, the elites' rejection of everything Africa leading to a dependency mentality. Lamenting on this self-depreciation of the African occasioned by colonialism and her ideology of westernization, Nyasani said:

We have adopted and assimilated wholesale whatever the west has to offer. The end result is not just a cultural betrayal but a serious case of self dehumanization and outright subversion both in terms of dignity and self-esteem. Indeed there is no race on earth that abhors its own culture and is so easily prepared to abdicate it and flirt with experimental ideas which promise no more than vanity to a large extent like the African race... African is simply overwhelmed and decisively submerged by the never-receding tide of cultural imperialism.[29]

This attitude is further expressed by Ogo Akubue Ogbata, thus "I have always suspected that Africans... are prone to self detest...We seem to be the only people on earth who would rather adopt an alien culture altogether than improve on our own. We prefer foreign languages, to the sound of our own, we prefer foreign names, foreign ways....all our hope is cast in foreign interventions..."[30] This alienation in the name of the Enlightenment Afrocentrists argue, deprive African societies and peoples foresight and understanding and the local interpretation of phenomena. This led to what some call the mimicry agenda in African societies. This agenda lies in doing 'like the master'. However, neither the master fully understands the complex values of either the servant nor the servant deeply captures the supposedly absolute objective verities of the masters' western values. Susan George commenting on this mimicry agenda said 'it mimics without understanding and copies without controlling. Lacking roots in local cultures or environment it quickly drops and withers ...' [31] Thus Africans have become a mimic people who mimic other societies and their life-style, use borrowed phrases, jargons as terminologies which have no real meaning to them and merely becloud the issues. The "mimicry of the centre" is used to qualify those who immerse themselves in the imported culture, denying their origins. It is highly believed that knowledge deprived of the assimilating elements which makes it natural to the one taught makes the person but a mere imitator.

Westernization then has been described by Chinweizu as a rampaging hurricane of barbarism from Europe which struck the African people and which swept through the continent disrupting and destroying many things, especially the people's culture in all its dimensions both material and cognitive. For him we are where we are today because the strong African cultural, religious scientific, educational system, and cosmogonies were destroyed or kept in state of suspended animation. Critics claim that much of the called values of westernization helped to disorientate African value systems, as it created almost the unidimensional man, the man for whom only the economy matters, re-engineering the African world, tastes, pursuits and relationships to fit into the materialistic individualistic, greedy, profit-oriented and consumerist culture and values of the western world: Authentic humanism sacrificed for economism, and human interest for profit motive.

This orientation of values for them has repercussion on all aspect of African life, as their models of development became conformist, depriving African societies of self-reliance and self-determination. Scientific rationality, positivism and objectivity became standards and ideals for meaning and efficiency, undermining the traditional values of African societies which were permeated with religious rationality, subjective meaning and communal beliefs, as measures of factual validity. The western materialistic ideology reduces the good and valuable to worldly success and material prosperity negating Africans desire for community and cosmic wholeness.[32] At the center of Westernized African society, there is some chaos, because the integrating spiritual and communal forces that held life activities together have given way to ravaging rationalistic, individualistic and materialistic forces, resulting in crisis upon crisis in all sectors of society. These crises have been expressed in various ways. For the Ghananian George Ayittey, the trouble with Africa is that there is no African solution to African problems, creating a rudderless continent, a sign of a missing tool from its spirit of self reliance.[33] For the Carter centre Africa is characterized by a disjuncture between the state pretensions to a monolithism and unanimity and a disorganized and ambiguous creativity on the part of African societies.[34]This means that the many African indigenous systems, and categories and beliefs which survived the western onslaught stagnated and never advanced beyond their medieval status or state, because the arrival of western modernity practically stopped the evolution of a proper African intellectuality or proper scientific and 
technological insights. Thus, it is claimed then that African indigenous knowledge systems suffered for years from the several strategies of disinformation embedded in the western (Eurocentric) colonial and post-colonial education, western religion, science and technology, as Africa was declared almost as a "terra incognito", cleaned the mind of Africans of any inherited knowledge in the name of reformation of the African mind and because of the brutal neglect of whatever belong to local genius and knowledge, inhibited the development of indigenous technology in Africa. It equally destabilized some of the existing process of technical growth, and indigenous manufacturing capacity was deliberately undermined to facilitate European productivity.[35]

Some Afrocentrists thus assert that westernization was an intellectual colonization because for them, the European not only colonized Africa but also African knowledge, not just to claim it as their own but also to disconnect Africans from their heritage and culture, and make them more easily manipulable and controllable. Hence it is argued that the colonization of the Africa mind was in fact the seizing of the African mind, the source of African mental arrest which Wade Nobles (1986) called conceptual incarceration (imprisonment) in the white man's belief system and criteriology. This has been regarded as the ultimate historical conquest of the African mind and world.[36]

Chinweizu will contend that Indians can remember their strong cultural and knowledge institutions and their journeys through time because they still have the institutions that have transmitted Hindu Lores and knowledge for thousands of years, from one generation to the next orally, by their methods, under their own authorities. The same can be said of many other peoples: Japan, China, South Korea, Arab nations. However, the case of Africa was that of total neglect and epistemicide. The argument continues that the African civilization was scattered, the African culture scattered, the African mind and mentality scattered. Some have regretted that, were it not for the arrogance of the western world and their grand plan to ensure the success of what some call epistemcide (the killing of the African indigenous knowledge) most of the indigenous knowledge would have taken their place today among the great insights of humanity. The cultural hegemony of colonialism which was a tool of westernization according to critics systematically destroyed indigenous system of survival, as Africa degenerated into a dependency syndrome as helpless receptacles of both pity and charity from the west.[37]

The crux of the contention of the critics here is that westernization has created the 'bekee wu Agbara' (white man is a spirit) syndrome, in which having been dazzled by the wonders of the white man's creativity, the African seems to have surrendered their own mental capacities, declaring it as irrelevant or incapable or superfluous, forgetting, it is argued, that if only Africans could regain their intellectual courage, self belief and call of destiny, they can make their own unique contribution from their own unique situations, gifts and endowments to invent an African modernity. In essence, westernization took the African intellectuals and elite captives and made them what some have called mental clones of the west or cultural "zombies". Historically, intellectuals of any civilization are the voices of that civilization to the rest of the world, as instruments of the development of the higher culture. Hence some hold that the tragedy of Africa is that her intellectuals were conquered by the west and by and large absconded and abdicated their roles as developers of African civilization, of which the grave consequences are the abysmal lack of creativity and originality in their thinking.

This means the need for a thorough review and re-invention of African mental ecology, philosophies and human cultural rationalizations which were hitherto neglected, or condemned as irrational and backward. They could be purified and elevated and used as a framework to counter many influences and negativities threatening humanity and African humanity in particular today and could be used in many beneficial ways in shaping a unique African modernity.[38] Many in the cultural and intellectual world including scientists and philosophers are coming to the realization that no point of view or perspective can exhaust the deep riches of reality which expresses itself in a multi-dimensional way. Hence people are seriously questioning the so called scientific objectivity and universal truths of western scientific rationality. Skeptics claim that the so called scientific values are offshoot of international opinion of Western cultural hegemony and political power and are therefore only partial and incomplete and therefore cannot be an exhaustive and objective representation of the human and physical reality.

Some africanists who are exploring the material, social, psychological and anthropological claims of the African human and physical world are today questioning the so called objectivity and universality of the western scientific laws and methods. And the post-modernists have pointed out that what has been presented in our social-political and intellectual traditions as knowledge, truth, objectivity and reason are actually merely, the effects of a particular form of social power, the victory of a particular way of representing the world, which presents itself as beyond mere interpretation, as truth itself. ${ }^{39}$ There are thus counter claims and attempts to demythologize the so called properties of universality, objectivity and rationality of modern sciences by showing that their claims on the final analysis are only socially established by the local culture and practice, not by any trans-cultural features of the scientific process. Hence some prefer to call western science and technology as ethno-science. 
The contention is that western scientific, technological and economic success does not amount to cultural or racial superiority and the inferiorization of the cultural traditions. Prof Sachs will observe:

... the vast differences in power contributed to faulty social theories of these differences that are still with us today. When a society is economically dominant, it is easy for its members to assume that such dominance reflects a deeper superiority whether religious, racial, genetic cultural or institutional rather than an accident of timing or geography. Thus the inequality of power and economics of the nineteenth century in favour of Europe was accompanied by spread of new forms of racism and culturalism which offered pseudo scientific qualifications for the vast inequalities that had opened. These theories in turn justified brute forms of exploitation of the poor through colonial rule, dispossession of the properties and lands of the poor by the rich and even slavery. [40]

The western calculating and instrumental rationality are being fiercely criticized as being responsible for the alienations of humans and humans relations; and laying emphasis more on physical productions than on the human itself. It is more a tool in the service of efficient calculations and technicity while refraining from saying anything about the value of the chosen ends. Thus, Assmann argued that the scientific methodologies ideologically constructed to animalize the Africa people needs to be problematized and new epistemologies developed based on the African cosmoogonies.[41]

In all then, critics of the westernization and iconoclastic models in the re-invention of the African mind hinged their arguments on its de-culturalization process, its paralysis and inferiorization of the African mind; its alienation and disempowerment of the African's knowledge and creative genius; its imposition of a culture which Africans have failed to master and will never master, hence the culture of ecclecticism and mimicry which creates a culture of superficiality. This in the final analysis is blamed on the culture of miss-education which according to many Afrocentrists like Chinweizu is the fountain-head of the African mental deformation and disorientation.

For them westernization brought a miss-education which omit, distort, and trivializes the role of African people in their seminal contributions to the world history and culture.[42]

The argument could not be presented better than in the words of Chinweizu:

It was a miss-education which under the mystique of "modernizing" me into some civilized condition had worked to infect me with intellectual meningitis that twist my cultural spine and rivet my admiring gaze upon Europe and the west. It is a miss-education which sought to withhold from me the memory of our true African past and to substitute instead an ignorant shame for whatever travesties Europe chose to present as the African past. . . it is a miss-education full of gaps and misleading pictures. .. It sought to train me automatically and habitually to employ the colonizers view point in all matters, in their strange belief that the racist supremicist anti-African interest is the universal humanist interest, all in the strange belief that the view defined by their ruthless greed is the rational, civilized view.[43]

Mudimbe agrees by pointing out that the discourse on African society's culture and peoples in the western libraries are invented to mark off Africa and the African as the other of the west and the western and served the interest of her western hegemony ordering the world with the West at its centre.[44] Western education became a system of ordering minds, bodies, souls according to models used in Europe.

This for critics was a mis-education which produced African peoples who identify with and embrace European history, traditions and cultures but who are ambivalent or indifferent towards African history, tradition and culture. Of course this indifference was due more to ignorance as they never were an important area in their own education and formation process. Perhaps the more damming criticism of westernization/modernization paradigm is that the white world that owns this civilization is themselves crying out about its dehumanization and de-personalization of man. They are lamentating it's extinguishing of social solidarity and community feeling, the loss of spontaneity, of warm family ties, of the culture of contentment, of the loss of the sacred and the loss for the respect and harmony with nature. They bemoan the culture of care, dread and anxiety, insatiable and infinite appetite, basic insecurity and stress and relentless pressure and acqusitiveness which have become the natural concomitant of the western liberal civilization.

The overall criticism of the westernization paradigm is that there is no way African mind and society can be positively re-invented through the same westernization that first distorted African humanity and history and delinked her from her roots. Thus, critics see westernization as the problem and not the solution. Surely, the African pessimists of westernization modernity will with A. Touraine query "we are all embarked on the adventure of modernity, the question is whether we are galley slaves or passengers with luggage who travel in hope".[45]

\section{Response To The Critiques.}

No one can raise the arguments of the pessimists of Westernization as a paradigm for the progress, reorientation and re-invention of the African mind and world without admitting that westernization or western 
liberal modernity and civilization as a wholesale engineering or transformation of Africa in the image and likeness of the western man, world and culture or a de-africanization process, is not only a generous idea, but very counterproductive and very unrealizable.

Most of the arguments against the westernization paradigm is its attempt to transform itself to a deafricanization process so that in order to be modern or progressive, one must be western in all its dimensions, economic, cultural, political, scientific etc. Surely, no one historical process, culture or civilization is the natural history of man, or the philosophy for man, as such; no one culture or civilization is perfect nor could exhaust the human reality or human possibility and capability. Thus western liberal ideas, civilization, values and methodologies are not the only ones possible for human consideration and for the progress of our societies and cultures. In fact, all historical process and civilizations are contingent.

However, it would equally be naïve and myopic for anyone not to recognize that our world, culture and configuration today bear an enormous and dominant influence and mark of western liberal modernity. Liberal West modernity wields enormous power, scientific power, technological power which permeates almost every area of our world culture and learning, including Africa. Are we to talk of her liberal political ideas which have almost became the political orthodoxy for modern states? Her liberal economic model in its varieties, which dominate the world economic Order that some like Francis Fukuyama declared some years ago with the fall of communism, that we might be witnessing "the end of history as such, that is the end point of ideological evolution and the universalization of western democracy as the final form of human government?[46]

It is even in the western scientific-technological prowess that the secret to her domination and achievements, through which they have discovered a big secret and to an extent the workings of nature and the capacity to harness them for man's good. Thanks to these, it is no longer debatable that the fate of humanity has remarkably improved and in a comparatively shorter time period: the eradication of much disease, an unprecedented material prosperity within a space of 200 years which made a good portion of the world to escape poverty, since all were judged to be poor at the threshold of liberal modernity.[47] Here efficiency, spirit of innovativeness, creativity, technicity, analycity and curiosity have help man to push back the frontier of ignorance, and expanded her horizon. Scientific breakthroughs, have led to tremendous medical advancement and destroyed many paralyzing and obstructive superstitions that have blinded the human spirit and held him in bondage for generations.

Hence it is impossible to imagine any group of people in the world as it stands today that could pretend to turn its back totally on western liberal civilization and her achievements and still expect to offer her people a prosperous and dignified living in the world.

The argument then is that, there is some way in which we can talk of some irreversibility of some aspect of our human world today. Talks of any configuration and modern web of primordial, idyllic and original Africa in which one can work out an African modernity untouched or untainted by western modernity, belong to the mythic mind, and completely disconnected from reality. There is no pure African primordiality and pure African man that has not drunk some dosage of westernization. Thus, a big chunk of the African world has been affected or changed irreversibly, for there is no way, Africans can undo all the historical encounters and influences of the western interventions in Africa, religiously, politically, intellectually, culturally and economically. Some of these have been permanently engraved within the structures of African society, culture and consciousness. Modern technology has come to impose its imperatives. Thus as Malinge Njeze would observe: "there are few if any geographical, cultural or biological purities. The interconnectedness and interdependence of geography, biology and culture have become much more complex and multiple".[48]

It must equally be asserted that the westernizing influences have not obliterated all of the African past, all about her culture and all about her indigenous endowments and genius. Some culturally, socially, technically and epistemic way and modes of doing and interpreting things are still very much alive in many segments of African society especially among the rural populations who had no access to formal education. In this respect $\mathrm{C}$. Acholonu said:

Africans must harness her indigenous resources... through promotion of research and rural literacy drives, collation and organization of materials from the remotest rural areas focusing on the lifestyles of rural people - their farming, hunting, crafts, healing, cooking, techniques. For these are the people, who still possesses the wisdom of our ancestors: the wisdom of the ancients. [49]

Even among a big chunk of the educated, one notices the influences of traditional beliefs, prejudices and world views in their actions and attitudes to things, peoples and events. Many African languages are alive and progressing and one cannot underrate the import of languages in creativity and in the construction of the philosophy of progress. The tragedy is that, most traditional ways of acting, doing, and thinking have stagnated and have never been properly articulated and developed.

The truth however about the promotion of knowledge growth and the reinvention of the African mind and a progressive orientation for the future lay neither in a westernization process that de-africanizes the indigenous worth, capacity, and capabilities nor in a combative world-view, full of rancour and hatred and well- 
entrenched anti-western rhetorics, venting anger on western objects which results, in an off-handed dismissal of all that is western and which hinders the African mind from engaging in a somewhat empassioned and honest analysis of the issues and events about the western world and her contributions, to humanity.

\section{Conclusion}

The way forward for Africa then is to face the reality of our world and the African world as it has historically emerged, and then articulate the best way forward from what we have. This means a critical, realistic approach, discernment and selection and eventually the synthesis of progressive methodologies, techniques, values, ideas that are capable of making Africa prosper and procure for her the best available in the order of thought, and action, from both internal and external sources, from the western civilization and other civilizations and from the indigenous African experiences. This means a critical openness to external sources, discoveries, intuitions, visions especially those that have been widely approved and attested to have been very beneficial to humanity at all times, especially those impossible to find, a better or more efficient valuable and progressive local alternative.

The openness to the external has been one of the greatest catalysts that have propelled almost all civilizations and cultures to greater heights of achievements and excellencies. For no one, people or culture has all the answers, or exhaust all the circumstances of human opportunities, creativity and possibilities. All peoples and cultures suffer from man's anthropological ignorance and limitedness of our existential horizons and hence the awareness that there is more to what we see and experience, more than we can learn. Hence the awareness that our best ideas and actions could always be perfected and there can always be a better way of doing or seeing things. Improvement always carries the potentiality of more improvement.

Even many of the elements of western liberal civilization which we tend to classify as European, were not originally of European origin. Western liberal civilization and achievements are a clear model and example of this critical openness to external resources. In the early part of this millennium, Europe learned much from the highly advanced science and technology of the Arabic, Indian and Chinese cultural areas, a process which included abundant examples of imitation and borrowings, the most important of which was the adoption of Arabic numerals. Elaborating further on this European openness, Appiah declared:

... Greece to which this West looks back was at the cross roads of culture of North Africa and the near East; the Spain that began the conquest of the new world had been deeply shaped by Islam; the Renaissance rediscovery of ancient learning owed a great deal to the Arabs who had preserved that tradition through the European Dark Ages; and the economic basis of modern capitalism depended on the labor of Africans, the gold and silver of the new world Indians and the markets of Asia. The west that has triumphed acquired its gun powder from china, the astronomical data on which was based the beginnings of the scientific revolution from the ancient near East. (Appiah)[50]

Sandra Harding will add that European sciences foraged in other cultures for elements of these cultures, native informants taught Europeans about the local flora, fauna, minerals and ores, climate, diseases and other threats, pharmacological remedies... and much of the knowledge traditions developed and stored in local cultures.[51] The Europeans having absorbed these things, the exogenous, triggered off the energy latent in European domestic conditions and Europe rapidly began to develop. The lesson from this and for Africans is that the good and beneficial ideas, and practices do not become bad because we do not like the face, race or the past activities of its original inventors or creators provided those ideas, values and practices are seen to be beneficial and salutary to the one or group, who wants to employ them.

This was the point Kwame Appiah was making when he said in agreement with Kwasi Wiredu that what makes a concept interesting is not whose it is but what it is, and how it deals with the realities that face those whose concept it is.[52]

If openness to the external is important, none could be more important to Africans than the western liberal civilization given its established efficiency and potency in many aspects of human life today. How could Africans turn their back to her established experimental reason, to her analytic reason, to her instrumental reason, to her management success and efficiency; to her spirit of enquiry and adventure; to her great democratic values? For as Luke Mbefo would observe, rejection of the West completely would involve the loss of Western technology which has proved very effective in the transformation and modernization of the continent and the world. Without mastering western technology, even in its transferred form, he argued, Africa would return to the pre-modern and would run the risk of greater exploitation by materially, stronger nations seeking markets and raw-materials; with that, Western education, science and technology which empower man to master nature and using it to bring about what they would like to be and to what ends.[53]

Of course we do not mean an indiscriminate wholesale consumption of the west, but a critical appropriation and the quest for the truth in the realization that our humanity including the African humanity, prosper in our ability to imaginatively think new thoughts, reconsider plans to life, fashion new world of possibilities, while acknowledging that each of us has a home that we should cherish, improve, perfect and 
defend. Thus, Africans might need science desperately, but it need not be had under the guidance of a scientistic and positivistic philosophy, a philosophy that concerns itself only with the means (technology) and not with the ends (its effects).

The openness to external knowledge resources and values and insights should constitute not a denial or neglect of African own proper civilizational values and achievements. African as we have said have also rich civilizational achievements in knowledge, in techniques and in cultures which could be further developed and refined to take their place among the best from other cultures. This also implies a serious and critical appreciation of what our horizon, our world and cultural experience can offer us in the light of the challenges and imperatives of living in our world today. We must have the courage to reject and abandon all progress resistant practices, beliefs and ideas and foster those things that offer us a favourable comparative advantage. Africa must promote practices not out of mere race pride or national pride, but those able to make real positive impart in the search for a holistic development of the African man and African world.

This is perhaps what Hountondji means when he says that for Africans local knowledge to become legitimate starting points of the production of developmentally relevant knowledge and skills; they must be subjected to critical and constant appraisal and modifications.[54] Africans must do a lot more to promote indigenous African languages because they embody a rich reservoir of peoples indigenous knowledge, values and understanding of their world and originality. To this Kwesi Prah would say:

the meaning of creativity is the extent to which people can reach new and innovative levels of thought-synthesis which permit interventions in reality. But thought itself is partly a function of linguistic insights and the ability to organize new ideas on the basis of commonly shared language symbols. This requires familiarity and command. It is therefore inconceivable to create and press the human genius into useful service in a language we can hardly use. In short, we create best in our home or first language.[55]

There could have been some element of exaggeration here yet, language is a form of symbolic representation that gives us indications of how we order our world, its linkages; its basic structures and sociocultural matrix and could provide basic categories of conceptualization and creativity in many aspects of intellectual, scientific, and technological activity.

We will further say here that, Africans historical encounter with western modernity can also be positively appreciated as not a mere alienating force but that which has helped to equip the African man with comparative consciousness, a quality of the mind which helps him to critically move in alternative worlds, alternative conceptualizations, alternative presentations both from western heritage and African heritage. With this he is equipped to critically evaluate, the achievements, creations, presentations, presuppositions, possibilities, then make a judicious judgment, in order to select the best outcome or attain an integral consciousness, which is not eclectic, but synthetic, offering Africans the best perceptions, and knowledge which they can have at any period in time. This synthetic consciousness differs from the present state of the African psyche which is more of compartmentalized consciousness, in which Africans operate now with mythopoetic consciousness, and at another time with western scientific consciousness, thus creating contradicting worlds, beliefs and actions and hence very unproductive.

This thought rejoins that of Wiredu in his belief that we become victims of colonial discourse by either uncritically carrying philosophical deadwood from our own past traditions or by uncritically accepting the colonial super impositions of foreign conceptual categories and values.

Modernisation thus is not "unthinkingly jettisoning" traditional ways of thought and adopting foreign habits, rather it is a process in which, "Africans, along with all other peoples, seek to attain a specifically human destiny".[56]

We have to exploit as much as judicious, the resources of our own indigenous conceptual schemes in our philosophical meditations, on even the most technical problems of contemporary philosophy and from external resources. The enterprise of knowledge is about comparing, contrasting, re-evaluating and adopting lasting and thoroughly examined points of view.[57]

\section{Reference}

[1] I. Walterstein, The Modern World-system as a civilization, Thesis Eleven, (20), 1988, 70-86; Cf. A. Toynbee, A study of History, (London: Themes and Hudson, 1972), 456.

[2] G.W.F. Hegel, (1968) Lectures on the History of philosophy. (London, 1968), 153; Cf. Davidson, B., The Ancient world and Africa, whose roots, Race and class, xxix, 2. 3 .

D. Hume, Essays and Treaties (1768).

W. E. Abraham, The Mind of Africa, (Univ. of Chicago Press, 1969) $3^{\text {rd }}$ edn., 39-40.

F. Ferre, Hellfire and lightening Rod, (N.Y: Orbis Books, 1993), 2.

M. Van Niekerk, Understanding Trends in African thinking - a critical Discussion, in P.H. Coetzee and A.P.J. Roux (Eds.), The African Philosophy Reader, (London and New York: Routledge, 1998), 58.

J. Sachs, The End of poverty: how we can make it happen in our life time, (Penguin Books, 2005), 351-352.

[8] C.E. Ayres, The theory of Economic progress. A study of the fundamentals of Economic development and cultural change, (New York: Schoeken Books, 1944). 
[9] W. Rodney, How Europe underdeveloped Africa, (Howard Univ. Press. 1982), 259.

[10] R. Horton, African thought versus western science, Part 1, from tradition to science, African Journal of International African Institute, 1967, 37 (1), 50-57.

[11] An Iconoclast is a breaker of images. It is historically connected to the $8^{\text {th }}-9^{\text {th }}$ century movement in which some people rose against the use of images in religious worship in the churches of the East, or a puritan movement in the $16^{\text {th }}-17^{\text {th }}$ century. So an iconoclast can be described as one who attacks cherished beliefs. Thus in a transferred sense, we see the westernization process by which all about the African past and mentality were destined for destruction or to neglect as an iconoclastic attitude.

[12] C. Achebe, Things Fall Apart, (New York: Ballantine Books, 1990), 162.

[13] V.Y. Mudimbe, The invention of African gnosis, philosophy and order of knowledge, (Bloomington Indiana Univ. Press, 1988), ix.

[14] Advice Viriri and Pascha Mungwine, African cosmology and the Duality of the Western Hegemony. The search for an African identity, Journal of Pan-African studies Vol. 3, No. 6, March 2010.

[15] Mugambi Mwite, Forget your past, thank colonialism Peoples digest, Jan 23-29, 1998, p.11

[16] O.P. Bitek, Song of Lawino and Song of O'col, (Heinemann, 1984), 115; Cf. J.K. Marah J.K., African people in the global Village: An Introduction to Pan-African Studies, (Lanham - New York, Oxford: Univ. Press of America, 1998), 194.

[17] E. Chielozena, Hate your Enemy: The anatomy of Resentment in African's cultural Resistance to the West, Global fellow seminar, (2005), Paper 2.

[18] E. Chielozena, Thought on the Nigerian mentality, Combative mode. March 1, 2009, Nigeria village square: windows internet explorer, (2010).

[19] T. Sono, Dilemma's of African intellectuals, South Africa: Political and cultural constraints, UNISA, (Pretoria, 1994).

[20] D. Ekpo, From Negritude to Post Africanism, Third Text, Vol.24, issue 2, (March 2010), 177-187.

[21] A. Irele, Contemporary thought in French-speaking Africa, In Albert Mosley (ed.) Africa Philosophy: selected readings, (N.J. Prentice-Hall, Englewood cliffs, 1986), 206.

[22] Masolo, African philosophy: In search of identity, (Bloomington Indiana: Indiana University Press, 1994$), 167$.

[23] J. Makang, Of the Good use of tradition, In Emmanuel Chukwudi Eze (ed.), Post-colonial African Philosophy, A critical reader, (Blackwell Publication, 1997), 332.

[24] See, The making of a Tradition: African Philosophy in the new millennium, Louisville: Department of philosophy by Dismas A. Masolo.

[25] K. Gyekye, Philosophy, culture and Technology, in Emmanuel Eze (ed.) Post African Philosophy: A critical Reader, (Blackwell Pub,1997). 174.

[26] A. Irele, (1986), 44

[27] K. Akosah-Sarpong, K., Juju clouds African way of thinking, The African Executive, 30, $6^{\text {th }}$ June, 2007.

[28] Masolo, (1994), 107-167.

[29] J.M. Nyasani, The African Psyche, Univ. of Nairobi Printing press, 1997), 126-128.

[30] O.A. Ogbata, A question of Identity, In Nigerian world.com, Jan. 17, 2005.

[31] S. George, The Debt Boomerang: how Third World debts harm us, (London: Pluto press 1992), xv-xvi.

[32] L. Senghor, Negritude, Optima (16, 1969), 8. Cf. Shutte, A., Philosophy for Africa, (Rodenbosch, Univ. of Cape Town press,1993), $52-54$

[33] G. Ayyitey, Africa in chaos, (New York: St. Martins, 1998), 227.

[34] Carter center, (1989), Perestroika without Glasnost, in Africa.

[35] C.T. Eyong et al., Literature and culture: the sustainability connection from an African perspective, Regional sustainable development review, (Oxford: Eolss Pub.,2000).

[36] W. Noble, African Psychology, Towards its reclamation, revitalization and rescension, (Oakland C.A, Black family Institute, 1986).

[37] C. Ngara, African ways of knowing and Pedagogy revisited, In Journal of Contemporary issues in Education, 22, (2007), 7-20.

[38] M. Nzewi, A contemporary study of musical arts, informed by African indigenous knowledge system, Vol. 4, Illuminations, reflections and explorations, (2007), 140.

[39] Giroux, Border-crossing: cultural workers and the politics of education, (New York: Routledge, 1992$), 53$.

[40] Sachs, (2005), 39 .

[41] J. Assman, The mind of Egypt, (Cambridge, London: Harvard Univ. Press, 2003).

[42.] U. Hotep, Decolonizing the African mind. Further analysis and strategy, Kwame Ture Youth Leadership Institute, (2003).

[43] Chinweizu, The West and the Rest of us, (London: Nok Pub., 1978), xiv.

[44] Mudimbe, (1988), ix

[45] A. Touraine, A critique of modernity, (Blackwell oxford, 1995)

[46] F. Fukuyama, The End of History and the last man, (New York - Toronto, Free Press and Maxwell Macmillan, 1992).

[47] Sachs, (2005).

[48] M. Njeze, Fallacies of the new Afrocentricism, A critical response to Kwame A. Appiah, Journal of theology for southern Africa, (99, Nov. 1997), 47-57.

[49] C. Acholonu, Motherism: The Afrocentric Alternative to Feminism, Alfa Pub., (1995), 125.

[50] K. Appiah, Fallacies of Eurocentricism and Afrocentricism, In AEI, enterprise Institute for Public policy Research; http//www.aei.org/publications/public. 1796 filter.all/pub details.asp.

[51] S. Harding, Is modern science an ethnoscience In Emmanuel Chukwudi Eze (ed.), (Blackwell Publication, 1997$), 63$.

[52] K. Appiah, In P.H.Coetzee and A.P.J. Roux (ed.), (1998), 125.

[53] L. Mbefo, The reshaping of African tradition, (Spiritans Pub., 1998), 94.

[54] P. Hountondji, African Philosophy, myth and Reality, (Bloomington Indiana Univ. Press 1996), $2^{\text {nd }}$ ed.

[55] K. Prah, Beyond the color line, Pan-African Disputations, selected sketches, letters, papers, Reviews, (Trenton-Asmara: African world press, 1998), 88.

[56] K. Wiredu, Philosophy and an African culture, (Cambridge: Cambridge Univ. Press, 1980), 43.

[57] K. Wiredu (1980), 130. 